Article

\title{
Supported Ni Catalyst for Liquid Phase Hydrogenation of Adiponitrile to 6-Aminocapronitrile and Hexamethyenediamine
}

\author{
Chengqiang Wang ${ }^{1}$, Zekun Jia ${ }^{1}$, Bin Zhen ${ }^{1,2}$ and Minghan Han ${ }^{1, *}$ \\ 1 Department of Chemical Engineering, Tsinghua University, Beijing 100084, China; \\ thuwcq@163.com (C.W.); jiazekun1991@163.com (Z.J.); zhenbin@tjut.edu.cn (B.Z.) \\ 2 College of Chemistry and Chemical Engineering, Tianjin University of Technology, Tianjin 300384, China \\ * Correspondence: hanmh@tsinghua.edu.cn; Tel.: +86-10-6278-1469
}

Received: 25 November 2017; Accepted: 30 December 2017; Published: 4 January 2018

\begin{abstract}
Supported Ni catalysts prepared under different conditions, for liquid phase hydrogenation of adiponitrile (ADN) to 6-aminocapronitrile $(\mathrm{ACN})$ and hexamethyenediamine $(\mathrm{HMD})$, were investigated. The highly reactive imine intermediate can form condensation byproducts with primary amine products (ACN and HMD), which decreased the yield coefficient of primary amines. The catalysts support, condition of catalyst preparation and dosage of additive were studied to improve the yield. A highly dispersed $\mathrm{Ni} / \mathrm{SiO}_{2}$ catalyst prepared by the direct reduction of $\mathrm{Ni}\left(\mathrm{NO}_{3}\right)_{2} / \mathrm{SiO}_{2}$ suppressed the condensation reactions by promoting the hydrogenation of adsorbed imines, and it gave the improved hydrogenation activity of $0.63 \mathrm{~mol} \cdot \mathrm{kg}_{\mathrm{cat}}{ }^{-1} \cdot \mathrm{min}^{-1}$ and primary amine selectivity of $94 \%$ when $\mathrm{NaOH}$ was added into the reactor.
\end{abstract}

Keywords: supported Ni catalyst; adiponitrile hydrogenation; 6-aminocapronitrile; hexamethyenediamine

\section{Introduction}

The hydrogenation of ADN to ACN and HMD is an important industrial process [1-4], which is mainly catalyzed by Raney Ni catalysts [5,6]. Although the skeleton structure of Raney Ni catalysts favors a high catalytic activity, it causes low mechanical strength and bad regeneration capability. In addition, a safety hazard also exists as the Raney Ni catalysts are flammable when exposed to air. Due to these drawbacks, many researchers have been working on developing supported Ni catalysts to replace Raney Ni. The use of a supported Ni catalyst can dramatically reduce the cost of the catalyst, making the process easy to operate and improving the safety of the hydrogenation reaction. The main challenge is that so far, the supported Ni catalysts are inferior in terms of catalytic activity and primary amine selectivity $[7,8]$.

The reaction scheme for the hydrogenation of $\mathrm{ADN}$ is given in Figure 1 [9-11]. ADN is hydrogenated to ACN and then to HMD. During the sequential hydrogenation, a highly reactive imine intermediate is formed, which has a strong tendency towards intermolecular condensation with the primary amine products (ACN and HMD) and intramolecular cyclization to undesired condensation byproducts and hexamethyleneimine (HMI). The formation of the primary amines has to compete with these side reactions. From the chemistry, it can be seen that increasing the hydrogenation activity of the catalyst would be an effective way to suppress the byproducts.

In this work, supported $\mathrm{Ni}$ catalysts were studied from several aspects, such as the type of support, conditions of catalyst preparation and dosage of additive, in order to increase the yield of primary amines. A highly dispersed $\mathrm{Ni} / \mathrm{SiO}_{2}$ catalyst prepared by the direct reduction of a $\mathrm{Ni}\left(\mathrm{NO}_{3}\right)_{2}$ precursor [12] was found able to promote the hydrogenation of the imine intermediate so that its performance was close to that of Raney Ni. 


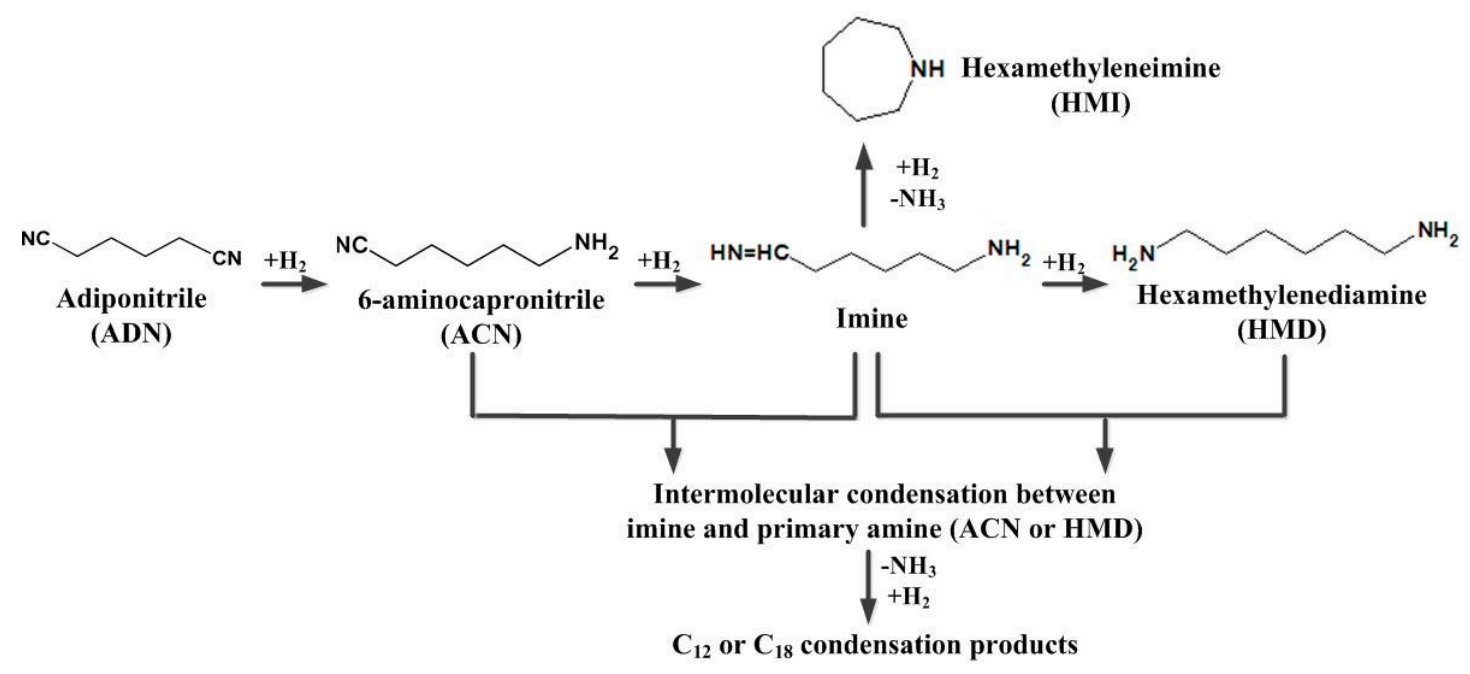

Figure 1. Mechanism of ADN hydrogenation.

\section{Results and Discussion}

\subsection{Catalyst Support}

Since the catalyst support has an important influence on the catalytic performance, the effect of different supports was investigated. Many oxides can be used as the support, among which $\mathrm{Al}_{2} \mathrm{O}_{3}$ and $\mathrm{SiO}_{2}$ are the most widely used. The characterization result of the specific surface area and pore structure of the $\mathrm{Al}_{2} \mathrm{O}_{3}, \mathrm{SiO}_{2}$ and $\mathrm{Ni} / \mathrm{Al}_{2} \mathrm{O}_{3}, \mathrm{Ni} / \mathrm{SiO}_{2}$ used are shown in Table 1 . The evaluation result in Table 2 showed the $\mathrm{Ni} / \mathrm{SiO}_{2}$ was better than $\mathrm{Ni} / \mathrm{Al}_{2} \mathrm{O}_{3}$ in terms of the selectivity of primary amines and condensation byproducts.

Table 1. Specific surface area and pore structure of the supports and the catalysts.

\begin{tabular}{cccc}
\hline Sample & Specific Surface Area/ $\mathbf{m}^{\mathbf{2}} \mathbf{- 1}^{\mathbf{1}}$ & Pore Volume $/ \mathbf{c m}^{\mathbf{3}} \cdot \mathbf{g}^{\mathbf{- 1}}$ & Average Pore Size/nm \\
\hline $\mathrm{Al}_{2} \mathrm{O}_{3}$ & 242 & 0.64 & 9.9 \\
$\mathrm{Ni} / \mathrm{Al}_{2} \mathrm{O}_{3}$ & 175 & 0.41 & 9.5 \\
$\mathrm{SiO}_{2}$ & 245 & 0.94 & 17.8 \\
$\mathrm{Ni} / \mathrm{SiO}_{2}$ & 190 & 0.72 & 17.4 \\
\hline
\end{tabular}

Table 2. Evaluation reaction result of $\mathrm{Ni} / \mathrm{SiO}_{2}$ and $\mathrm{Ni} / \mathrm{Al}_{2} \mathrm{O}_{3}$.

\begin{tabular}{cccccc}
\hline \multirow{2}{*}{ Catalysts } & \multirow{2}{*}{ Catalytic Activity/mol $\cdot \mathbf{k g}_{\mathbf{c a t}}{ }^{-\mathbf{1}} \cdot \mathbf{m i n}^{-\mathbf{1}}$} & \multicolumn{4}{c}{ Selectivity/\% } \\
\cline { 3 - 5 } & & ACN & HMD & HMI & Condensation Byproducts \\
\hline $\mathrm{Ni} / \mathrm{SiO}_{2}$ & 0.25 & 50 & 4 & 9 & 37 \\
$\mathrm{Ni} / \mathrm{Al}_{2} \mathrm{O}_{3}$ & 0.29 & 43 & 4 & 8 & 45 \\
\hline
\end{tabular}

Using the bifunctional mechanism [13], it is believed that in a nitrile hydrogenation system, the hydrogenation reactions are catalyzed by metal sites while condensation reactions are catalyzed by acid sites. This would indicate that the acidic properties of the support are crucial to the catalytic performance. A stronger acidity favors the conversion of nitrile but decreases the selectivity to primary amines. The $\mathrm{NH}_{3}$-TPD data for $\mathrm{Al}_{2} \mathrm{O}_{3}$ and $\mathrm{SiO}_{2}$ and their corresponding catalysts are presented in Figure 2a. $\mathrm{Al}_{2} \mathrm{O}_{3}$ has a large $\mathrm{NH}_{3}$ desorption peak in the temperature range from 100 to $500{ }^{\circ} \mathrm{C}$ while $\mathrm{SiO}_{2}$ does not. After the introduction of the $\mathrm{Ni}, \mathrm{Ni} / \mathrm{Al}_{2} \mathrm{O}_{3}$ still showed an obvious $\mathrm{NH}_{3}$ desorption peak in contrast to $\mathrm{Ni} / \mathrm{SiO}_{2}$ as shown in Figure $2 \mathrm{~b}$. The acid sites can absorb imine intermediate and primary amine and cause them to react with each other so that condensation products are produced, which lead to the decreased selectivity of the target products. 


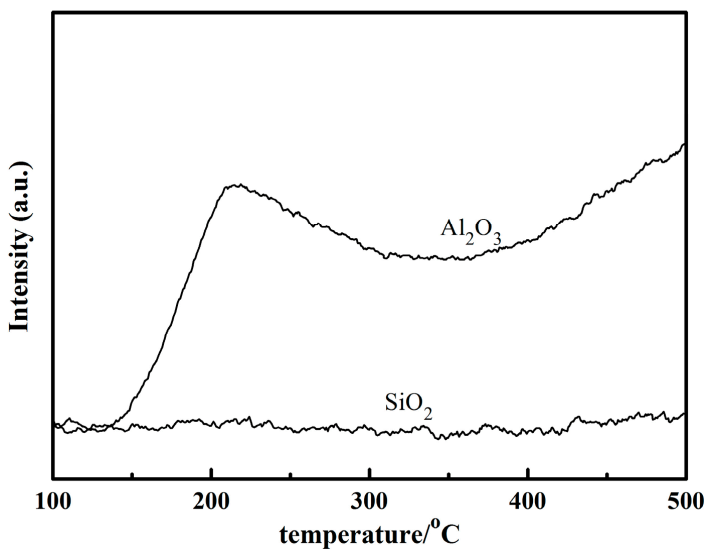

(a)

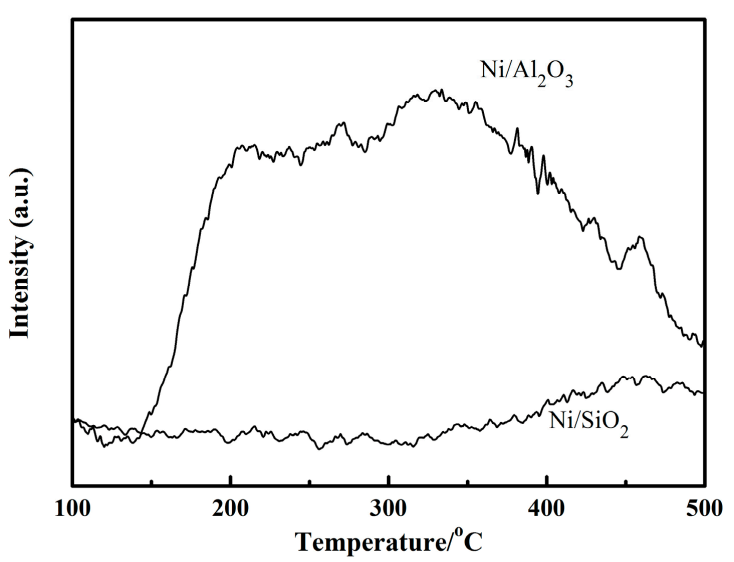

(b)

Figure 2. $\mathrm{NH}_{3}-\mathrm{TPD}$ of (a) Supports and (b) Catalysts.

Therefore, $\mathrm{SiO}_{2}$ is the more suitable support for the hydrogenation of ADN to ACN and HMD, and $\mathrm{SiO}_{2}$ was used as the support in the following study.

\subsection{Direct Reduction Method}

The supported Ni catalyst was prepared by the wetness incipient impregnation method, which consists of three steps: impregnation, calcination and reduction. After calcination and reduction, the $\mathrm{Ni}\left(\mathrm{NO}_{3}\right)_{2}$ loaded on the supports became metal particles with catalytic activity. The calcination and reduction are key steps and have important influence on the catalytic performance.

Table 3 shows mean particle sizes of Ni estimated by the two independent methods, TEM and XRD analysis [14]. Figure 3 showed the TEM images of two catalysts. The particle size of nickel on the $\mathrm{Ni}_{\mathrm{DR}} / \mathrm{SiO}_{2}$ is around $7 \mathrm{~nm}$, while that on the $\mathrm{Ni}_{\mathrm{CR}} / \mathrm{SiO}_{2}$ is much larger. XRD analysis results of the catalysts show the similar information, 6.4 and $17.7 \mathrm{~nm}$, respectively.

Table 3. Ni particle size of $\mathrm{Ni}_{\mathrm{CR}} / \mathrm{SiO}_{2}$ and $\mathrm{Ni}_{\mathrm{DR}} / \mathrm{SiO}_{2}$ from TEM and $\mathrm{XRD}$ analysis.

\begin{tabular}{|c|c|c|}
\hline Sample & Ni Particle Size(a) ${ }^{1} / \mathrm{nm}$ & Ni Particle Size(b) ${ }^{2} / \mathrm{nm}$ \\
\hline $\mathrm{Ni}_{\mathrm{CR}} / \mathrm{SiO}_{2}$ & 19 & 17.7 \\
\hline $\mathrm{Ni}_{\mathrm{DR}} / \mathrm{SiO}_{2}$ & 7 & 6.4 \\
\hline
\end{tabular}

${ }^{1}$ Estimated by TEM analysis. ${ }^{2}$ Calculated by XRD analysis according to Scherrer equation.

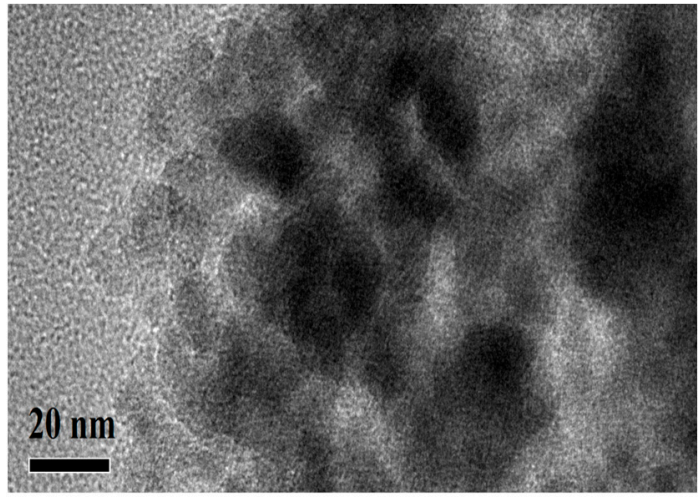

(a)

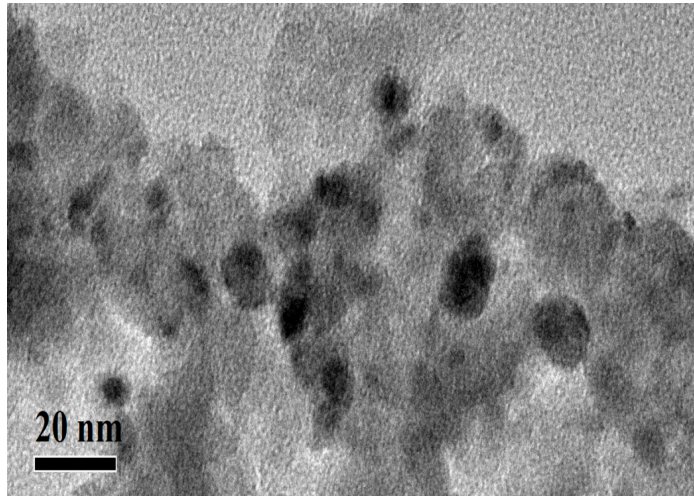

(b)

Figure 3. TEM images of (a) $\mathrm{Ni}_{\mathrm{CR}} / \mathrm{SiO}_{2}$ and (b) $\mathrm{Ni}_{\mathrm{DR}} / \mathrm{SiO}_{2}$. 
The $\mathrm{H}_{2}$ uptake was $76.2 \mu \mathrm{mol} / \mathrm{g}$ by $\mathrm{Ni}_{\mathrm{DR}} / \mathrm{SiO}_{2}$ while that by $\mathrm{Ni}_{C R} / \mathrm{SiO}_{2}$ was $15.4 \mu \mathrm{mol} / \mathrm{g}$, corresponding to the active nickel areas of 30.0 and $6.0 \mathrm{~m}^{2} / \mathrm{g}$ [15]. We can conclude that $\mathrm{Ni}_{\mathrm{DR}} / \mathrm{SiO}_{2}$ had a superior $\mathrm{Ni}$ dispersion of $4.50 \%$ while that of $\mathrm{Ni}_{\mathrm{CR}} / \mathrm{SiO}_{2}$ is $0.90 \%$, which is in accordance with the TEM and the $\mathrm{XRD}$ analysis. $\mathrm{Ni}\left(\mathrm{NO}_{3}\right)_{2} / \mathrm{SiO}_{2}$ catalyst precursor would be totally reduced at $700{ }^{\circ} \mathrm{C}$ from $\mathrm{H}_{2}$-TPR profiles. The $\mathrm{H}_{2}$-chemisorption data showed the $\mathrm{H}_{2}$ adsorption capacity of a catalyst partially reduced at $450{ }^{\circ} \mathrm{C}$. This means that $\mathrm{H}_{2}$-chemisorption data here cannot be used to calculate the mean particle size accurately.

Figure 4 showed the XRD patterns of the catalysts. The characteristic diffraction peaks of $\mathrm{NiO}$ in $\mathrm{Ni}_{C} / \mathrm{SiO}_{2}$ are obvious, which indicated that the nickel mainly existed in the form of nickel oxide. After the reduction in $\mathrm{H}_{2}, \mathrm{Ni}_{\mathrm{CR}} / \mathrm{SiO}_{2}$ showed a very sharp $\mathrm{Ni}$ peak while $\mathrm{Ni} \mathrm{DR}_{\mathrm{DR}} / \mathrm{SiO}_{2}$ showed both $\mathrm{NiO}$ and $\mathrm{Ni}$ diffraction peaks. Louis et al. [16] have studied supported $\mathrm{Ni}$ catalyst and found existence of nickel phyllosilicates, which were located at the surface of catalyst precursor after nickel nitrate impregnated onto silica. The nickel phyllosilicates act as anchoring sites for metallic Ni particles and suppress the formation of large Ni particles. However, calcination before reduction leads to the formation of larger metal particles and to their aggregation. This is probably due to the partial decomposition of nickel phyllosilicates during calcination, the breaking of the anchoring sites for impregnated nickel, which favors nickel migration. Direct reduction of $\mathrm{Ni}\left(\mathrm{NO}_{3}\right)_{2} / \mathrm{SiO}_{2}$ was a moderate reduction process, which sacrificed the reduction degree but gave a superior Ni dispersion.

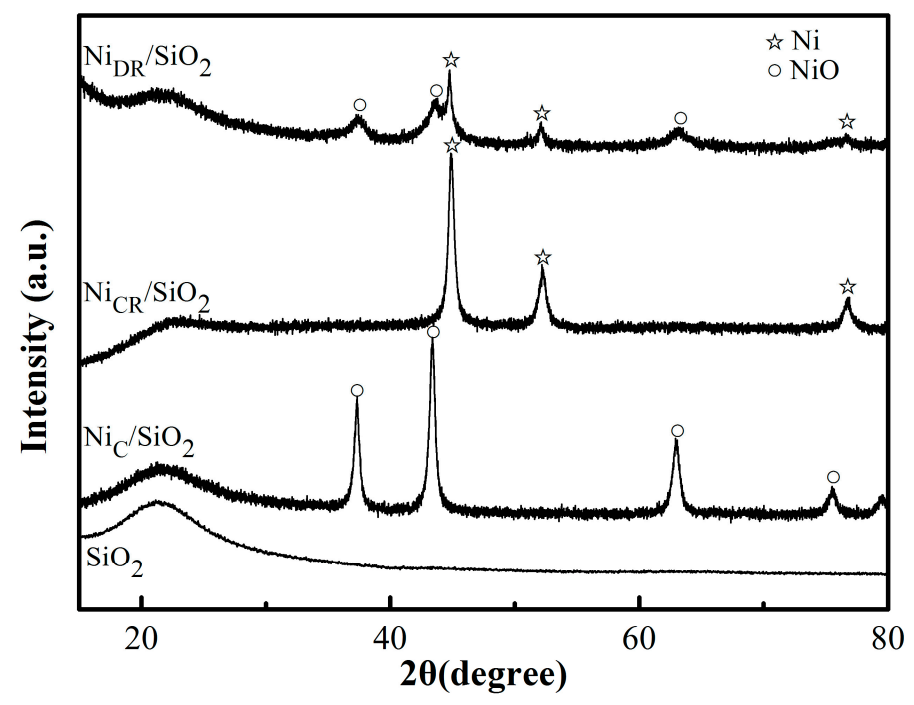

Figure 4. XRD pattern of $\mathrm{SiO}_{2}, \mathrm{Ni}_{\mathrm{C}} / \mathrm{SiO}_{2}, \mathrm{Ni}_{\mathrm{CR}} / \mathrm{SiO}_{2}$ and $\mathrm{Ni} \mathrm{DR}_{\mathrm{D}} / \mathrm{SiO}_{2}$.

As described above, the two catalysts prepared by the different methods had different microstructures, which probably caused their catalytic performance for hydrogenation of ADN to be different. Table 4 shows the evaluation result of the catalysts. $\mathrm{Ni}_{\mathrm{DR}} / \mathrm{SiO}_{2}$ exhibited a better hydrogenation activity of $0.56 \mathrm{~mol} \cdot \mathrm{kg}_{\mathrm{cat}}{ }^{-1} \cdot \mathrm{min}^{-1}$ compared to $\mathrm{Ni}_{\mathrm{CR}} / \mathrm{SiO}_{2}$ with $0.25 \mathrm{~mol} \cdot \mathrm{kg}_{\mathrm{cat}}{ }^{-1} \cdot \mathrm{min}^{-1}$. The selectivity to the primary amine products over $\mathrm{Ni}_{\mathrm{DR}} / \mathrm{SiO}_{2}$ was higher than that over $\mathrm{Ni}_{\mathrm{CR}} / \mathrm{SiO}_{2}$, which, respectively, were $79 \%$ and $54 \%$. Meanwhile, the selectivity to condensation byproducts were inhibited over $\mathrm{Ni}_{\mathrm{DR}} / \mathrm{SiO}_{2}$, which decreased from $37 \%$ to $3 \%$. In the sequential reaction, shown in Figure 1, the highly reactive imine intermediate can further react along three pathways: further hydrogenation, intramolecular condensation to HMI, and intermolecular to condensation byproducts. The three pathways are parallel, that is, the formation of primary amine competes with the side reactions. $\mathrm{Ni} \mathrm{DR}_{\mathrm{DR}} / \mathrm{SiO}_{2}$ exhibited a superior hydrogenation activity, which promoted the hydrogenation and improved the selectivity to ACN and HMD. 
Table 4. Evaluation reaction result of $\mathrm{Ni}_{\mathrm{CR}} / \mathrm{SiO}_{2}$ and $\mathrm{Ni}_{\mathrm{DR}} / \mathrm{SiO}_{2}$.

\begin{tabular}{lccccc}
\hline \multirow{2}{*}{ Catalysts } & \multirow{2}{*}{ Catalytic Activity/Mol· $\mathbf{k g}_{\mathrm{cat}}{ }^{-\mathbf{1}} \cdot \mathbf{m i n}^{-\mathbf{1}}$} & \multicolumn{3}{c}{ Selectivity/\% } \\
\cline { 3 - 5 } & & $\mathbf{A C N}$ & HMD & HMI & Condensation Byproducts \\
\hline $\mathrm{Ni}_{\mathrm{CR}} / \mathrm{SiO}_{2}$ & 0.25 & 50 & 4 & 9 & 37 \\
$\mathrm{Ni}_{\mathrm{DR}} / \mathrm{SiO}_{2}$ & 0.50 & 66 & 13 & 18 & 3 \\
\hline
\end{tabular}

The condensation byproducts were secondary and tertiary amines with a high molecular weight which were not eluted and cannot be detected in the GC analysis. The product mixture was analyzed by a mass spectrometer to confirm the existence of condensation byproducts. The result is shown in Figure 5. The mass to charge ratio of protonated HMI, ACN and HMD are, respectively, $m / z=100$, 113,117 . The peaks of $m / z=200 \sim 300$ indicated the formation of $C_{12}$ and $C_{18}$ oligomers. These showed clearly that the condensation byproducts from $\mathrm{Ni}_{\mathrm{DR}} / \mathrm{SiO}_{2}$ was decreased, which verified the GC evaluation result.

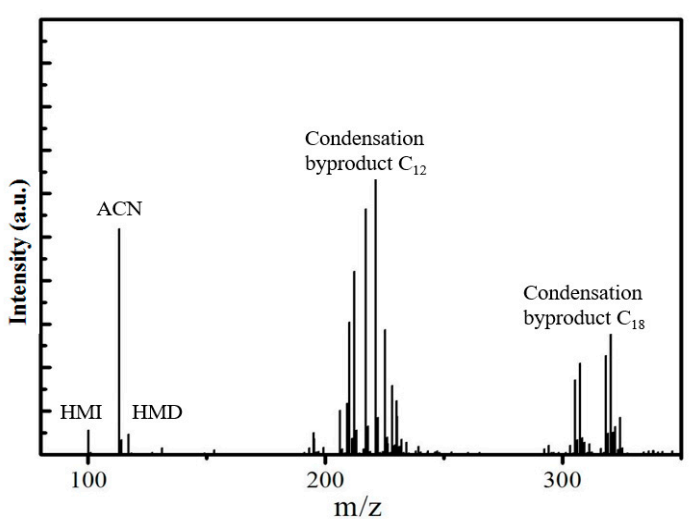

(a)

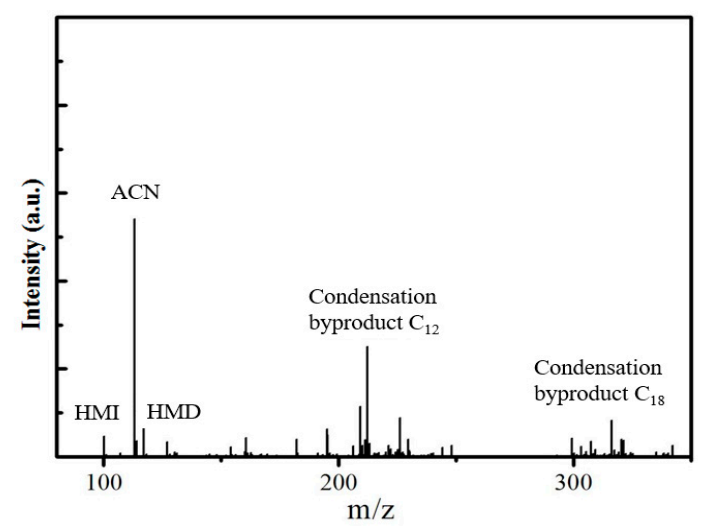

(b)

Figure 5. Mass spectra of (a) $\mathrm{Ni}_{\mathrm{CR}} / \mathrm{SiO}_{2}$ and (b) $\mathrm{Ni}_{\mathrm{DR}} / \mathrm{SiO}_{2}$.

$\mathrm{Ni}_{\mathrm{DR}} / \mathrm{SiO}_{2}$ had a higher $\mathrm{H}_{2}$ adsorption capacity from $\mathrm{H}_{2}$ uptake result, which would indicate that amines and imine intermediates are more abundantly adsorbed on $\mathrm{Ni}_{\mathrm{DR}} / \mathrm{SiO}_{2}$. The $\mathrm{C}$ atoms of imines were subjected to nucleophilic attack by $\mathrm{N}$ atoms of the amines [17], leading to the formation of a secondary imine which can be further hydrogenated to $\mathrm{HMI}$. Ni $\mathrm{DR}_{\mathrm{DR}} / \mathrm{SiO}_{2}$ was more selective for intramolecular side reaction. As seen in Table 4, the selectivity to $\mathrm{HMI}$ over $\mathrm{Ni}_{\mathrm{CR}} / \mathrm{SiO}_{2}$ was $9 \%$ while that over $\mathrm{Ni}_{\mathrm{DR}} / \mathrm{SiO}_{2}$ was $18 \%$. From this point, further developing of the supported Ni catalyst prepared by the direct reduction method is still necessary. The conditions of catalyst preparation and reaction conditions have to be optimized to inhibit the formation of HMI and improve the selectivity to primary amines.

\subsection{Reduction Teamperature}

The microstructure of supported Ni catalyst prepared by direct reduction method is affected by reduction temperature significantly. The TEM images of catalysts reduced at different temperature are shown in Figure 6. The mean particle sizes of Ni became larger with the increase of reduction temperature obviously. 


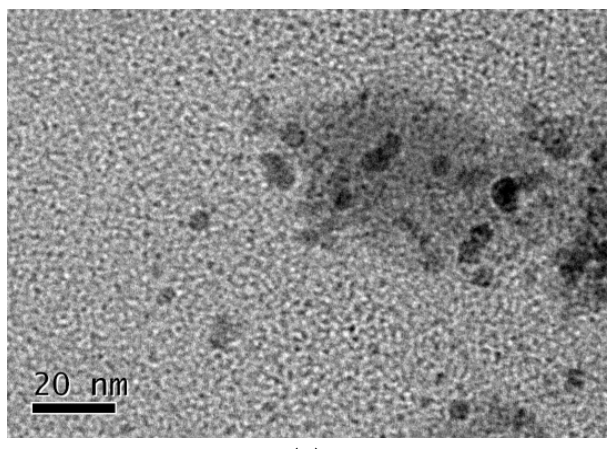

(a)

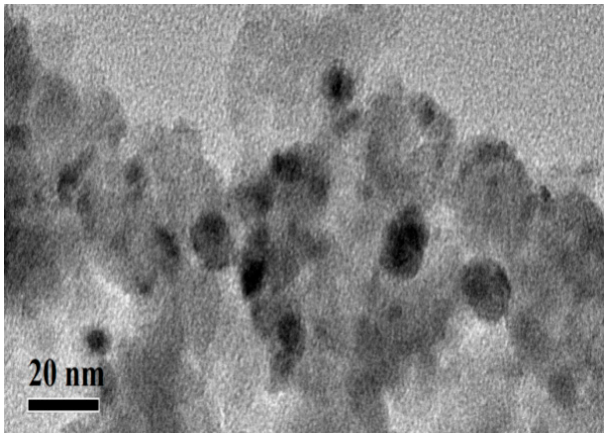

(c)

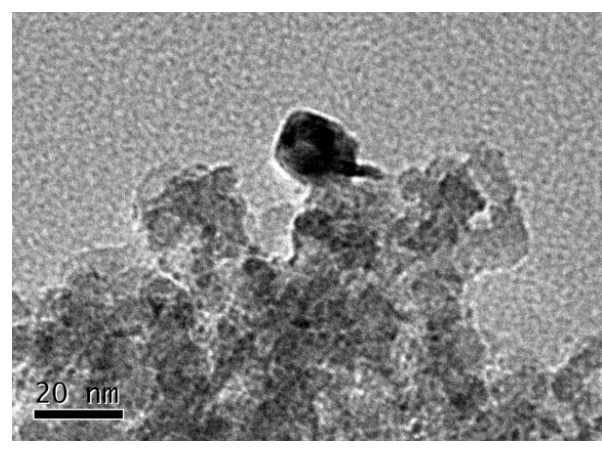

(b)

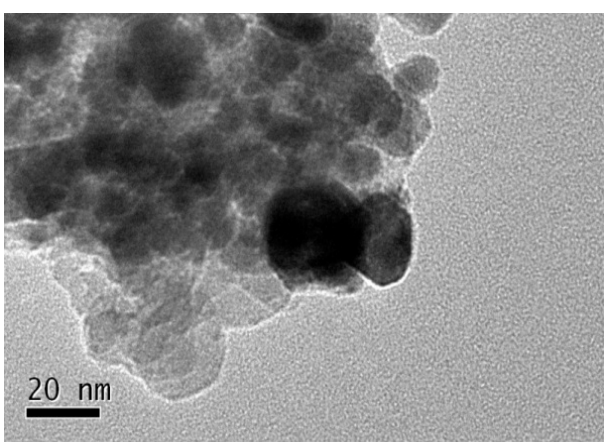

(d)

Figure 6. TEM images of the catalysts reduced at different temperatures: (a) $350{ }^{\circ} \mathrm{C}$; (b) $400{ }^{\circ} \mathrm{C}$; (c) $450{ }^{\circ} \mathrm{C}$; (d) $500{ }^{\circ} \mathrm{C}$.

The $\mathrm{H}_{2}$-TPR profiles of $\mathrm{Ni}\left(\mathrm{NO}_{3}\right)_{2} / \mathrm{SiO}_{2}$ were given in Figure 7 . The TPR profiles of the impregnated catalysts, performed without any previous calcination, exhibit three peaks of hydrogen consumption at 300,400 , and about $550{ }^{\circ} \mathrm{C}$, attributed to the decomposition of nickel nitrate into $\mathrm{NiO}$, the reduction of $\mathrm{NiO}$ and the reduction of nickel phyllosilicates. After TPR up to $700{ }^{\circ} \mathrm{C}$, the nickel is totally reduced. Before complete reduction, the nickel phyllosilicates are probably located at the interface between silica and the remaining nickel, for which they act as anchoring sites. During TPR, after nitrate decomposition, the NiO particles located on the phyllosilicates are reduced into $\mathrm{Ni}^{0}$ at $400{ }^{\circ} \mathrm{C}$ without any migration. Between 400 and $700{ }^{\circ} \mathrm{C}$, the increase in metal particle size is due not only to $\mathrm{NiO}$ migration induced by thermal effect but also to the reduction of the phyllosilicates by the weakening of the anchoring strength.

The $\mathrm{H}_{2}$-TPR profiles of $\mathrm{Ni}\left(\mathrm{NO}_{3}\right)_{2} / \mathrm{SiO}_{2}$ are in accordance with the TEM analysis of the four catalysts reduced at $350,400,450$ and $500{ }^{\circ} \mathrm{C}$, respectively.

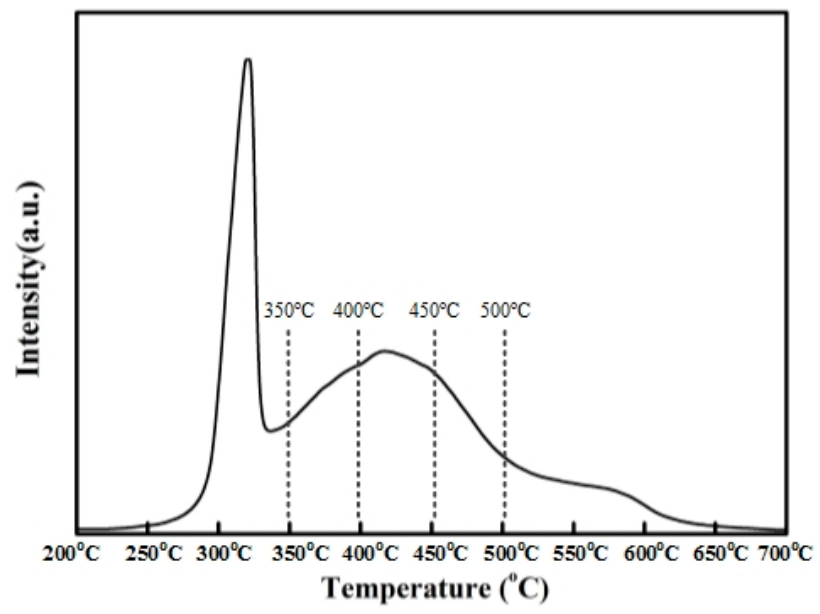

Figure 7. $\mathrm{H}_{2}$-TPR of catalyst precursors. 
Figure 8 presents the evaluation result of the four catalysts. The catalytic activity first decreased and then increased with the increase of reduction temperature, which can be explained by the reduction degree and Ni dispersion. With the increase of reduction temperature, the reduction degree of the catalysts became higher while the Ni dispersion became lower because the nickel phyllosilicates were gradually decomposed. $\mathrm{Ni} / \mathrm{SiO}_{2}$ reduced at $350{ }^{\circ} \mathrm{C}$ had a high hydrogenation activity because of its high $\mathrm{Ni}$ dispersion. When the reduction temperature was increased to $400{ }^{\circ} \mathrm{C}$ and $450{ }^{\circ} \mathrm{C}$, the migration and aggregation of $\mathrm{Ni}$ particles led to a lower metallic Ni dispersion, which caused the catalytic activity decrease. Although the $\mathrm{Ni}$ dispersion of $\mathrm{Ni} / \mathrm{SiO}_{2}$ reduced at $500{ }^{\circ} \mathrm{C}$ became even lower, the catalytic activity became higher because of its higher reduction degree. In conclusion, Ni dispersion was the key factor to affect the catalytic activity for the reduction temperature range from $350{ }^{\circ} \mathrm{C}$ to $450{ }^{\circ} \mathrm{C}$ while the reduction degree was the key factor in the temperature range from $450{ }^{\circ} \mathrm{C}$ to $500{ }^{\circ} \mathrm{C}$, which explained the variation of catalytic activity.

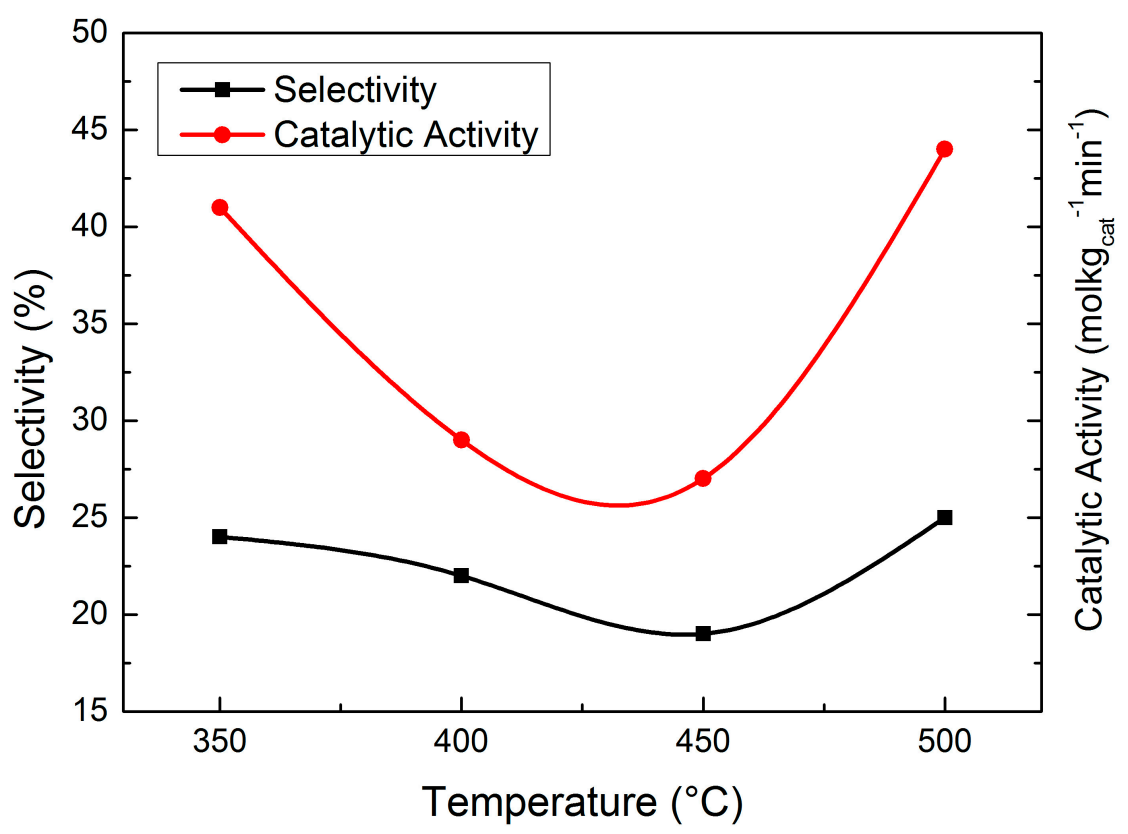

Figure 8. Evaluation result of catalysts reduced at different temperatures.

$450{ }^{\circ} \mathrm{C}$ was considered the optimum temperature for the reduction when both catalytic activity and selectivity to HMI were taken into account.

\subsection{Additive}

Most of the side reactions are deamination reactions as shown in Figure 1. Thermodynamically, adding an alkaline substance as additive to the liquid reaction system would benefit the catalytic activity and selectivity to primary amines $[5,18]$. In ADN hydrogenation, $\mathrm{H}_{2}$ and nitrile adsorbed on metallic Ni first and then they reacted with each other to imine intermediates and amines. Imines and amines desorbed from the catalyst with difficulty [19], which would not only suppress the following hydrogenation of nitriles, but also promote the condensation side reactions. The addition of an alkaline substance increases the electron density of metallic Ni on the catalyst surface, which would benefit the desorption of imine and amine [20].

$\mathrm{NaOH}$ was chosen as an additive to improve the $\mathrm{Ni}_{\mathrm{DR}} / \mathrm{SiO}_{2}$ catalyst. The evaluation result is presented in Figure 9 and Table 5. The mass ratio $\mathrm{NaOH} / \mathrm{Ni}$ was used as the independent variable. With $\mathrm{NaOH} / \mathrm{Ni}$ increasing, the catalytic activity rose from $0.39 \mathrm{~mol} \cdot \mathrm{kg}_{\text {cat }}{ }^{-1} \cdot \mathrm{min}^{-1}$ to $0.63 \mathrm{~mol} \cdot \mathrm{kg}_{\text {cat }}{ }^{-1} \cdot \mathrm{min}^{-1}$ and the selectivity to condensation byproducts decreased from $12 \%$ to $1 \%$ while that to HMI decreased from $21 \%$ to $5 \%$. When the $\mathrm{NaOH} / \mathrm{Ni}$ was raised to 0.5 , the primary 
selectivity was as high as $94 \%$. Clearly, the effect of $\mathrm{NaOH}$ on the catalytic activity and product selectivity was positive.

Table 5. Evaluation reaction result of the catalysts with different $\mathrm{NaOH} / \mathrm{Ni}$ mass ratio.

\begin{tabular}{cccccc}
\hline \multirow{2}{*}{$\mathbf{N a O H} / \mathbf{N i}$} & \multirow{2}{*}{ Catalytic Activity/mol$\cdot \mathbf{k g} \mathbf{c a t}^{\mathbf{- 1}} \cdot \mathbf{m} \mathbf{m i n}^{-\mathbf{1}}$} & \multicolumn{4}{c}{ Selectivity/\% } \\
\cline { 3 - 5 } & & ACN & HMD & HMI & Condensation Byproducts \\
\hline 0 & 0.39 & 55 & 12 & 21 & 12 \\
0.1 & 0.50 & 66 & 13 & 18 & 3 \\
0.3 & 0.56 & 70 & 21 & 7 & 2 \\
0.5 & 0.63 & 70 & 24 & 5 & 1 \\
\hline
\end{tabular}

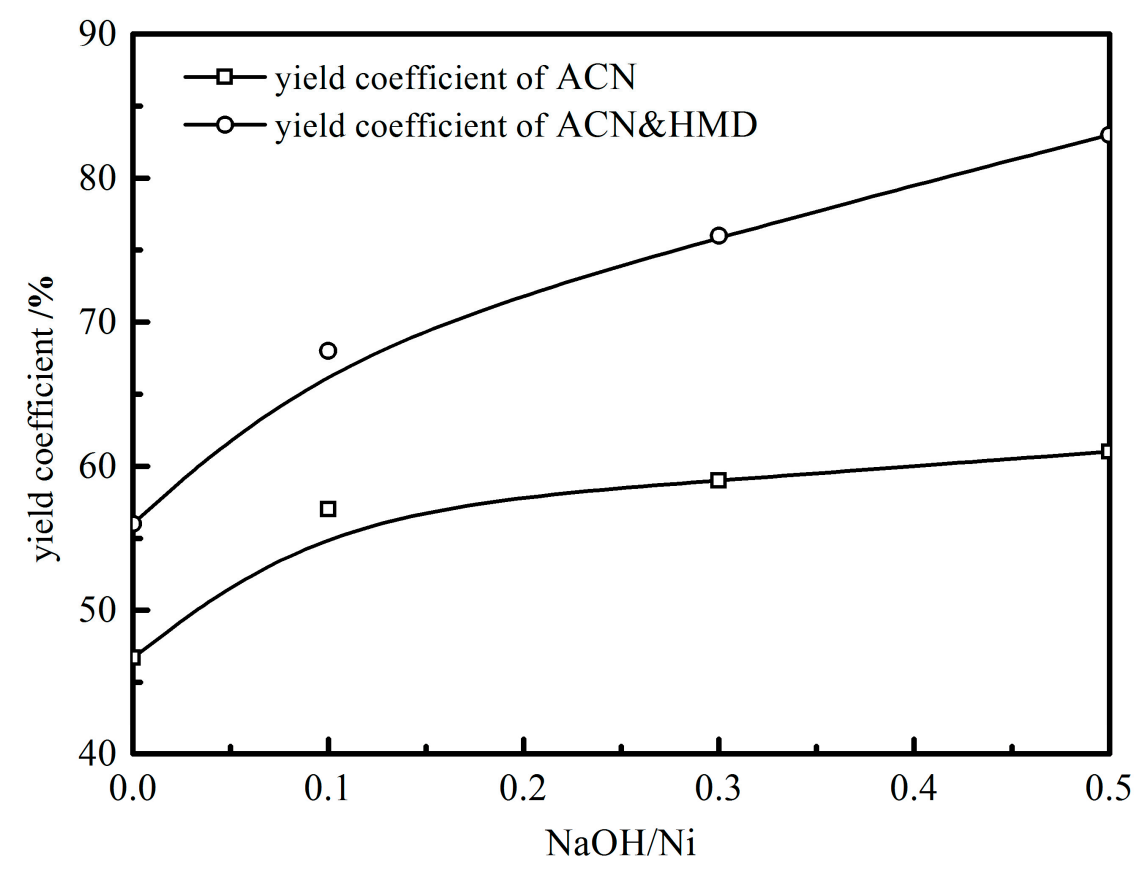

Figure 9. Evaluation result of catalysts with the use of different $\mathrm{NaOH} / \mathrm{Ni}$ ratios.

The addition of $\mathrm{NaOH}$ improved the hydrogenation activity and improved the target products selectivity significantly. After the introduction of $\mathrm{NaOH}$, the performance of $\mathrm{Ni}_{\mathrm{DR}} / \mathrm{SiO}_{2}$, reduced at $450{ }^{\circ} \mathrm{C}$, is as excellent as Raney $\mathrm{Ni}$, which is presented in Table 6 .

Table 6. Evaluation reaction result of the $\mathrm{Ni}_{\mathrm{DR}} / \mathrm{SiO}_{2}$ and Raney Ni.

\begin{tabular}{cccccc}
\hline \multirow{2}{*}{ Catalysts } & \multirow{2}{*}{ Catalytic Activity/mol $\cdot \mathbf{k g}_{\mathrm{cat}} \mathbf{- 1}^{\mathbf{- 1}} \cdot \mathbf{m i n}^{-\mathbf{1}}$} & \multicolumn{4}{c}{ Selectivity/\% } \\
\cline { 3 - 5 } & & ACN & HMD & HMI & Condensation Byproducts \\
\hline $\mathrm{Raney} \mathrm{Ni}$ & 0.61 & 78 & 17 & 1 & 4 \\
$\mathrm{Ni}_{\mathrm{DR}} / \mathrm{SiO}_{2}$ & 0.63 & 70 & 24 & 5 & 1 \\
\hline
\end{tabular}

\section{Materials and Methods}

\subsection{Catalyst Preparation}

The supported Ni catalysts were prepared by incipient wetness impregnation, which included three steps: impregnation, calcination and reduction. $\mathrm{Ni} / \mathrm{SiO}_{2}$ catalyst prepared by the direct reduction (DR) of $\mathrm{Ni}\left(\mathrm{NO}_{3}\right)_{2} / \mathrm{SiO}_{2}$ in $\mathrm{H}_{2}$ was denoted as $\mathrm{Ni}_{\mathrm{DR}} / \mathrm{SiO}_{2}$. For comparison, another catalyst prepared by calcination and reduction (CR) was denoted as $\mathrm{Ni}_{\mathrm{CR}} / \mathrm{SiO}_{2}$. They were prepared as follows. The loading amount of nickel was $20 \mathrm{wt} . \%$. 
$\mathrm{Ni}_{\mathrm{DR}} / \mathrm{SiO}_{2}$ : First, $\mathrm{SiO}_{2}$ (Alfa Aesar, Haverhill, MA, USA) was soaked in an aqueous solution of $\mathrm{Ni}\left(\mathrm{NO}_{3}\right)_{2}(98 \%$, Alfa Aesar) at room temperature. Then, the mixture was treated with ultrasonic waves for $2 \mathrm{~h}$ and dried at $80^{\circ} \mathrm{C}$ for $12 \mathrm{~h}$. Finally, the catalyst precursor was reduced in $\mathrm{H}_{2}$ flow at $450{ }^{\circ} \mathrm{C}$ for $8 \mathrm{~h}$.

$\mathrm{Ni}_{\mathrm{CR}} / \mathrm{SiO}_{2}$ : The impregnated and dried $\mathrm{Ni}\left(\mathrm{NO}_{3}\right)_{2} / \mathrm{SiO}_{2}$ was calcined at $450{ }^{\circ} \mathrm{C}$ for $4 \mathrm{~h}$ and then reduced in $\mathrm{H}_{2}$ flow. The other steps were the same as those for $\mathrm{Ni}_{\mathrm{DR}} / \mathrm{SiO}_{2}$. Before reduction, the calcined (C) catalyst was denoted as $\mathrm{Ni}_{\mathrm{C}} / \mathrm{SiO}_{2}$.

\subsection{Catalyst Characterization}

The specific surface area and pore structure of support and catalyst were determined by $\mathrm{N}_{2}$ adsorption with a Quadrasorb SI instrument. The crystalline phase of the catalysts was characterized by a Bruker Advance D8 X-ray diffractometer with a $\mathrm{Cu} \mathrm{K} \alpha$ radiation source. The $\mathrm{H}_{2}$ uptake of the catalysts was determined by $\mathrm{H}_{2}$ chemisorption on a Quantachrome ChemBET Pulsar TPR/TPD instrument. The active $\mathrm{Ni}$ area was calculated assuming $\mathrm{H} / \mathrm{Ni}_{\text {surface }}=1$ and a surface area of $6.5 \times 10^{-20} \mathrm{~m}^{2}$ per Ni atom. A JEM-2010 transmission electron microscope was employed to examine the Ni particle size of catalysts. Some product samples were analyzed by mass spectrometry (MS model: Q Exactive) to identify the relative amount of condensation byproducts.

\subsection{Catalytic Reaction}

The hydrogenation of ADN was carried out in a stainless-steel autoclave equipped with a temperature control system and magnetic stirrer. Typically, $5 \mathrm{~g}$ ADN (98\%, Alfa Aesar, Haverhill, MA, USA), $80 \mathrm{~mL}$ of methanol ( $>99.5 \%$, Beijing Chemical Works, Beijing, China), $5 \mathrm{~g}$ pre-reduced catalyst and $0.1 \mathrm{~g} \mathrm{NaOH}(>96.0 \%$, Beijing Chemical Works) were added into the reactor. The hydrogenation conditions were: $80^{\circ} \mathrm{C}, 3 \mathrm{MPa}, 500 \mathrm{rpm}$. The products were sampled online and analyzed by a gas chromatograph (GC 7890F, Techcomp Instrument Company, Kwai Chung, Hong Kong) equipped with a flame ionization detector and a KB-624 capillary column $(30 \mathrm{~m} \times 0.32 \mathrm{~mm} \times 1.8 \mu \mathrm{m}$, Kromat). The condensation byproducts were high molecular weight secondary and tertiary amines which were not eluted in the GC. Phenylamine was used as the internal standard to determine the content of ADN, ACN, HMD and HMI. The catalytic activity, the conversion of ADN and the selectivity to ACN and HMD were calculated as:

$$
\begin{gathered}
\text { Catalytic Activity }=\frac{\text { moles of converted ADN }}{\text { Time } \times \mathrm{m}_{\text {Cat }}} \\
\text { ADN Conversion }=\frac{\text { moles of converted ADN }}{\text { moles of ADN feedstock }} \times 100 \% \\
\text { ACN Selectivity }=\frac{\text { moles of ACN }}{\text { moles of converted ADN }} \times 100 \% \\
\text { HMD Selectivity }=\frac{\text { moles of HMD }}{\text { moles of converted ADN }} \times 100 \%
\end{gathered}
$$

\section{Conclusions}

Supported Ni catalysts for the liquid phase hydrogenation of ADN were investigated. The following conclusions are based on the results and discussion:

1. The support affects the catalytic performance of supported Ni catalysts by providing original acid sites, which promote the condensation side reactions and decrease the selectivity to primary amines. $\mathrm{SiO}_{2}$ is chosen as the support in this work providing less original acid sites.

2. The catalyst prepared by the direct reaction method, without a prior calcination step, gave smaller $\mathrm{Ni}$ particles, this is, a higher $\mathrm{Ni}$ dispersion and $\mathrm{H}_{2}$ uptake capacity, which improved the catalytic activity and inhibited the intermolecular condensation side reaction. 
3. The reduction temperature had an appreciable effect on the catalytic performance of $\mathrm{Ni}_{\mathrm{DR}} / \mathrm{SiO}_{2}$. $450{ }^{\circ} \mathrm{C}$ was regarded as a preferable temperature to suppress the intramolecular condensation reaction to HMI.

4. The addition of $\mathrm{NaOH}$ into the reaction system improved the hydrogenation activity and significantly improved the target products selectivity. When the $\mathrm{NaOH} / \mathrm{Ni}$ mass ratio was increased to 0.5 , the selectivity to primary amines attained $94 \%$.

Author Contributions: M.H., Z.J. and C.W. conceived and designed the experiments; Z.J. and C.W. performed the experiments; Z.J. and C.W. analyzed the data; B.Z. and C.W. wrote the paper.

Conflicts of Interest: The authors declare no conflict of interest.

\section{References}

1. Dahlhoff, G.; Niederer, J.P.M.; Hoelderich, W.F. Epsilon-Caprolactam: New by-product free synthesis routes. Catal. Rev. Sci. Eng. 2001, 43, 381-441. [CrossRef]

2. Tolman, C.A.; Mckinney, R.J.; Seidel, W.C.; Druliner, J.D.; Stevens, W.R. Homogeneous Nickel-Catalyzed Olefin Hydrocyanation. Adv. Catal. 1985, 33, 1-46. [CrossRef]

3. Brunelle, J.; Seigneurin, A.; Sever, L. Method for Cyclizing Hydrolysis of an Aminonitrile Compound into Lactam. U.S. Patent 6479658B1, 12 November 2002.

4. Leconte, P. Process for Preparing Lactams. U.S. Patent 20120095212A1, 19 April 2012.

5. Ziemecki, S.B. Selective Low Pressure Hydrogenation of a Dinitrile to an Aminonitrile. U.S. Patent 5151543A, 29 September 1992.

6. Boschat, V.; Brunelle, J.P.; Darrier, B.; Chevaljer, B.; Bobet, J.L. Hemihydrogenation Method for Dinitriles. U.S. Patent 6521779B1, 18 February 2003.

7. Ziemecki, S.B.; Ionkin, A.S. Aminonitrile Production. U.S. Patent 6080884A, 27 June 2000.

8. Liao, H.; Liu, S.; Hao, F.; Liu, P.; You, K.; Liu, D.; Luo, H. Liquid phase hydrogenation of adiponitrile to 6-aminocapronitrile and hexamethylenediamine over potassium doped $\mathrm{Ni} /$ alpha- $\mathrm{Al}_{2} \mathrm{O}_{3}$ catalyst. React. Kinet. Mech. Catal. 2013, 109, 475-488. [CrossRef]

9. Chen, B.; Dingerdissen, U.; Krauter, J.G.E.; Rotgerink, H.G.J.L.; Mobus, K.; Ostgard, D.J.; Panster, P.; Riermeier, T.H.; Seebald, S.; Tacke, T. New developments in hydrogenation catalysis particularly in synthesis of fine and intermediate chemicals. Appl. Catal. A Gen. 2005, 280, 17-46. [CrossRef]

10. Tichit, D.; Durand, R.; Rolland, A.; Coq, B.; Lopez, J.; Marion, P. Selective half-hydrogenation of adiponitrile to aminocapronitrile on Ni-based catalysts elaborated from lamellar double hydroxide precursors. J. Catal. 2002, 211, 511-520. [CrossRef]

11. Hoffer, B.W.; Moulijn, J.A. Hydrogenation of dinitriles on Raney-type Ni catalysts: Kinetic and mechanistic aspects. Appl. Catal. A Gen. 2009, 352, 193-201. [CrossRef]

12. Jia, Z.; Zhen, B.; Han, M.; Wang, C. Liquid phase hydrogenation of adiponitrile over directly reduced $\mathrm{Ni} / \mathrm{SiO}_{2}$ catalyst. Catal. Commun. 2016, 73, 80-83. [CrossRef]

13. Verhaak, M.J.F.M. The selective hydrogenation of acetonitrile on supported nickel-catalysts. Catal. Lett. 1994, 26, 37-53. [CrossRef]

14. Nakagawa, Y.; Nakazawa, H.; Watanabe, H.; Tomishige, K. Total Hydrogenation of Furfural over a SilicaSupported Nickel Catalyst Prepared by the Reduction of a Nickel Nitrate Precursor. ChemCatChem 2012, 4, 1791-1797. [CrossRef]

15. Li, H.X.; Xu, Y.P.; Li, H.; Deng, J.F. Gas-phase hydrogenation of adiponitrile with high selectivity to primary amine over supported Ni-B amorphous catalysts. Appl. Catal. A Gen. 2001, 216, 51-58. [CrossRef]

16. Louis, $\mathrm{C}$; Cheng, Z.; Che, M. Charaterization of $\mathrm{Ni} / \mathrm{SiO}_{2}$ catalysts during impregnation and future thermal activation treatment leading to metal particles. J. Phys. Chem. 1993, 97, 5703-5712. [CrossRef]

17. Braun, J.V.; Blessing, G.; Zobel, F. Katalytische hydrierungen unter druck bei gegenwart von nickelsalzen, VI: Nitrile. Berichte der Deutschen Chemischen Gesellschaft (A B Ser.) 1923, 56, 1988-2001. [CrossRef]

18. Sanchez, K.M. Preparation of 6-Aminocapronitrile. U.S. Patent 5296628A, 22 March 1994. 
19. Huang, Y.Y.; Adeeva, V.; Sachtler, W.M.H. Stability of supported transition metal catalysts in the hydrogenation of nitriles. Appl. Catal. A Gen. 1991, 182, 365-378. [CrossRef]

20. Balladur, V.; Fouilloux, P.; deBellefon, C. Monometallic Ni, Co and Ru, and bimetallic NiCr, NiTi and CoFe Ziegler-Sloan-Lapporte catalysts for the hydrogenation of adiponitrile into hexamethylenediamine: Effect of water and dopants. Appl. Catal. A Gen. 1995, 133, 367-376. [CrossRef]

Sample Availability: Samples of the compounds are available from the authors.

(C) 2018 by the authors. Licensee MDPI, Basel, Switzerland. This article is an open access article distributed under the terms and conditions of the Creative Commons Attribution (CC BY) license (http://creativecommons.org/licenses/by/4.0/). 